\title{
Etika Kesehatan pada Persalinan Melalui Sectio Caesarea Tanpa Indikasi Medis
}

\author{
Bioethics in Childbirth through Sectio Caesaria \\ without Medical Indication
}

\author{
Dumilah Ayuningtyas $^{{ }^{*}}$, Ratih Oktarina ${ }^{1}$, Misnaniarti ${ }^{2}$, Ni Nyoman Dwi Sutrisnawati ${ }^{1}$ \\ ${ }^{1}$ Departemen Administrasi dan Kebijakan Kesehatan, Fakultas Kesehatan Masyarakat Universitas Indonesia \\ ${ }^{2}$ Bagian Administrasi Kebijakan Kesehatan, Fakultas Kesehatan Masyarakat Universitas Sriwijaya \\ ('dumilah.ayuningtyas@gmail.com)
}

\begin{abstract}
ABSTRAK
Angka persalinan dengan sectio caesarea di Indonesia terbilang cukup tinggi. WHO menyatakan, angka sectio caesarea maksimum sekitar 10 sampai 15\%. Oleh karena itu, perlu dikaji pengambilan keputusan melakukan tindakan sectio caesarea berdasarkan prinsip-prinsip etika kesehatan. Penelitian ini menggunakan pendekatan kualitatif, yang dilaksanakan di rumah sakit dan klinik persalinan di Jakarta. Pengumpulan data melalui wawancara mendalam pada narasumber tenaga medis fungsional, bidan dan manajer rumah sakit. Data dianalisis menggunakan content analysis. Hasil penelitian menunjukkantrend persalinan sectio caesarea sangat tinggi mencapai $70 \%$. Persalinan sectio caesarea hampir seluruhnya disebabkan indikasi medis. Trend persalinan melalui tindakan sectio caesarea yang sangat tinggi tidak serta merta menunjukkan bahwa terdapat hal yang bertentangan dengan etika pelayanan kesehatan. Banyak faktor di luar indikasi medis, baik dari sisi ibu maupun bayi, yang menyebabkan sectio caesarea dipilih, antara lain faktor psikis ibu, peralatan medis yang tidak siap digunakan untuk persalinan normal, hak pasien dalam memilih tindakan medis yang ingin dilakukan, regulasi yang lemah dalam mengendalikan rumah sakit yang menawarkan paket sectio caesarea, serta regulasi yang dipandang merusak sistem jasa medis yang telah berjalan baik sehingga mendorong moral hazard dari para dokter untuk membiarkan adanya permintaan persalinan melalui sectio caesarea tanpa indikasi medis yang adekuat.
\end{abstract}

Kata kunci : Etika medis, deontologi, sectio caesarea

\section{ABSTRACT}

The rate sectio caesarea in Indonesia is quite high. World Health Organization states that the number sectio caesarea maximum of about 10 to 15\%. Therefore, it is necessary to study the decision-making action sectio caesarea based on the principles of bioethics. This study used a qualitative approach with descriptive and analytic analysis, conducted in 2014 in hospitals and maternity clinics in Jakarta. Data collection through interviews on interviewees such as functional medical workers, midwives and hospital managers. Results showed the trend of sectio caesarea very high reaching 70\%. Sectio caesarea is almost entirely due to medical indications. Trend sectio caesarea very high does not necessarily indicate that there are things that are contrary to the ethics of health care. Many factors beyond medical indications, both in the mother and baby, which causes sectio caesarea been, among others: the maternal psychological, medical equipment that is not ready for normal delivery, the right of patients to choose medical treatment to do, weak regulation in controlling hospital offers a package sectio caesarea, as well as regulation is deemed damaging medical services system is already working well so as to encourage moral hazard of the doctors to let their demand for childbirth through sectio caesarea without adequate medical indications. Keywords : Bioethics, deontologi, Sectio Caesarea 


\section{PENDAHULUAN}

Word Health Organization (WHO) mempertimbangkan rata-rata tindakan sectio caesarea berkisar 5\% sampai $15 \%$ sebagai range maksimum yang ditargetkan pada intervensi penyelamatan nyawa dalam hal persalinan. ${ }^{1}$ Pada tahun 2004, di Amerika Serikat rata-rata sectio caesarea meningkat hingga 29,1\%, di Inggris dan Wales juga telah mencapai $21,4 \%$, meningkat 5 kali lipat sejak tahun $1971 .^{2,3}$ Selain itu, tercatat pula pada tahun 2001 hingga 2003, angka kejadian sectio caesarea di Kanada adalah 22,5\%. ${ }^{4}$ Data tersebut menunjukkan bahwa secara global, khususnya di negara-negara maju, bahwa angka tindakan persalinan melalui sectio caesarea terbilang tinggi. Pada tahun 70 -an permintaan sectio caesarea adalah sebesar 5\%, kini lebih dari 50\% ibu hamil menginginkan operasi sectio caesarea. ${ }^{5}$

Tidak hanya di level dunia, angka persalinan dengan sectio caesarea di Indonesia juga terbilang cukup tinggi. Hasil survei Gulardi dan Basalamah, terhadap 64 rumah sakit di Jakarta tahun 1993, menunjukkan dari 17.665 kelahiran, sebanyak $35,7-55,3 \%$ melahirkan dengan tindakan sectio caesarea. Sebanyak 19,5-27,3\% di antaranya karena adanya komplikasi Cephalopelvik Disproportion (CPD, ukuran lingkar panggul ibu tidak sesuai dengan ukuran lingkar kepala janin). Berikutnya, sectio caesarea akibat perdarahan hebat yang terjadi selama persalinan sebanyak 11,9$21 \%$ dan sectio caesarea karena janin sungsang berkisar antara 4,3-8,7\%. ${ }^{6}$

Sectio caesarea merupakan tindakan medis yang diperlukan untuk membantu persalinan yang tidak bisa dilakukan secara normal akibat masalah kesehatan ibu atau kondisi janin. Tindakan ini diartikan sebagai pembedahan untuk melahirkan janin dengan membuka dinding perut dan dinding uterus atau vagina atau suatu histerotomi untuk melahirkan janin dari dalam rahim. Namun demikian, tindakan sectio caesarea tidak lagi dilakukan semata-mata karena pertimbangan medis, tetapi juga termasuk permintaan pasien sendiri atau saran dokter yang menangani seperti hasil penelitian yang dibahas sebelumnya. Sectio caesarea memang memungkinkan seorang wanita yang akan bersalin untuk merekayasa hari persalinan sesuai keinginan lebih besar. ${ }^{7}$ Menurut Kasdu, ${ }^{6}$ proses persalinan sectio caesarea kadang dilakukan kare- na adanya kepercayaan yang berkembang di masyarakat yang mengaitkan waktu kelahiran dengan peruntungan nasib anak dengan harapan apabila anak dilahirkan pada tanggal dan jam tertentu akan memperoleh rezeki dan kehidupan yang lebih baik. Selain itu, menurut penelitian yang dilakukan di salah satu RS di Medan menyatakan bahwa faktor selain kepercayaan yang dapat mempengaruhi keputusan ibu untuk melakukan sectio caesarea antara lain kesepakatan suami istri, pengetahuan, faktor sosial, kecemasan persalinan normal, faktor ekonomi dan pekerjaan. ${ }^{8}$

Hal tersebut menjadi beberapa faktor yang menyebabkan jumlah tindakan sectio caesarea semakin tak meningkat dan mendapat respon dari akademisi, professional di bidang medis, maupun pemerintah. Pasalnya, tindakan medis tersebut lebih berisiko dibandingkan persalinan normal. Selain itu, dampak sectio caesarea pun tidak hanya dirasakan ibu melainkan juga bagi bayi, bahkan ayah dari bayi. Komplikasi yang bisa timbul pada sectio caesarea adalah infeksi puerperal, perdarahan, bisa terjadi pada waktu pembedahan cabang-cabang atonia uteria ikut terbuka atau karena atonia uteria; komplikasi lain karena luka kandung kencing, embolisme paru dan deep vein thrombosis; dan terjadi ruptur uteri pada kehamilan berikutnya. ${ }^{9}$

Menurut hasil survei global WHO yang dilakukan di 9 (Sembilan) negara Asia pada tahun 2007 dan 2008, di Kamboja, China, Nepal, Filipina, Srilangka, Thailand, dan Vietnam diketahui bahwa persentase persalinan SC sekitar 27,3\%. Survei ini meneliti hampir 108.000 persalinan di 122 rumah sakit. Sectio caesarea dapat meningkatkan morbiditas dan mortalitas maternal, sehingga SC seharusnya dilakukan hanya karena adanya indikasi medis. ${ }^{10}$

Tenaga medis tentunya paham mengenai risiko dilakukannya tindakan sectio caesarea, termasuk risiko medis akibat tindakan ini. Namun demikian, banyak tenaga medis yang mempermudah izin tindakan ini hanya karena kemauan pasien atau kondisi medis yang sebenarnya dapat diatasi tanpa sectio caesarea. Hal ini terkait dengan bioetika atau etika kesehatan yang salah satu prinsipnya adalah benifience, mendahulukan kepentingan atau keselamatan pasien, tidak hanya pada konteks kekinian melainkan juga pada konteks di 
masa depan dan mengusahakan agar kebaikan atau manfaat dari tindakan yang diambil itu lebih banyak dibandingkan dengan suatu keburukannya.

Adanya trend peningkatan tindakan sectio caesarea (SC) di sejumlah rumah sakit, baik di RS swasta maupun RS pemerintah, padahal risiko klinis terhadap ibu yang melahirkan melalui operasi SC lebih besar dibandingkan dengan risiko persalinan normal (pervaginam). Risiko psikologis juga tidak dapat dihindarkan karena rasa sakit pasca operasi caesarea yang lebih lama serta adanya risiko pada bayi. Risiko akibat pasca SC yang merugikan ini perlu dikaji lebih jauh dari segi etika kesehatan, mulai dari proses pengambilan keputusan dokter dalam melakukan operasi sectio caesarea. Oleh karena itu, tujuan penelitian ini adalah untuk menganalisis tindakan sectio caesarea berdasarkan prinsip-prinsip etika kesehatan.

\section{BAHAN DAN METODE}

Penelitian menggunakan pendekatan kualitatif, dengan analisis deskriptif dan analitik. Pengambilan data dilakukan dengan wawancara mendalam terhadap dokter obstetri dan gynekologi di rumah sakit dan bidan klinik mandiri. Pendekatan ini digunakan untuk memahami gambaran tindakan sectio caesarea yang tanpa indikasi medis dan mendapatkan materi untuk menganalisis sisi etika kesehatan dalam tindakan tersebut.

Penelitian dilaksanakan dari Januari hingga April 2014, di rumah sakit dan klinik persalinan di Jakarta (pada 3 RS umum pemerintah dan 3 RS swasta). Pengumpulan data melalui wawancara mendalam menggunakan pedoman wawancara terhadap 5 (lima) narasumber yang terdiri dari tenaga medis fungsional (dokter obstetri dan gynekology), bidan dan manajer (direktur) rumah sakit.

Pembahasan tentang etik berdasarkan empat teori etika antara lain: konsekuensialisme, deontologi, etika hak dan intuisionisme. ${ }^{11}$ Prinsip-prinsip etika dalam persalinan sectio caesarea (tanpa indikasi medis) berdasarkan pendekatan 'empat prinsip' yang dikembangkan oleh Beauchamp dan Childress dalam bukunya The Principles of Biomedical Ethics ${ }^{12}$ meliputi: 1) prinsip autonomi (berhak menentukan sendiri), 2) prinsip beneficience (berbuat baik), 3) prinsip non-maleficence (tidak merugikan), 4) prinsip juctice (keadilan) untuk menilai tindakan sectio caesarea yang dilakukan oleh dokter apakah sudah sesuai/ tidak sesuai dengan etika kesehatan. Selanjutnya intisari jawaban dibuat dalam matriks hasil penelitian, untuk mendapatkan kesimpulan dari jawaban semua narasumber. Data dianalisis menggunakan content analysis dengan cara membandingkan hasil dengan teori atau konsep yang ada, hasil penelitian sejenis sebelumnya dan justifikasi peneliti.

\section{HASIL}

Berdasarkan hasil wawancara pada pihak manajerial rumah sakit, diketahui bahwa trend persalinan melalui Sectio Caesarea (SC) terbilang sangat tinggi, seperti kutipan dari informan berikut:

"RS ini adalah top level hospital. Kalau dilihat dari angka persalinan, sejumlah kurang lebih 4000 persalinan per tahun, 40\% di antaranya adalah dengan $S C^{\prime \prime}$

(Informan 1).

"Untuk pelayanan SC ini besar proporsinya adalah sekitar 30-32\%. Akan tetapi, pasien yang dilayani SC di sini pun di antaranya adalah pasien rujukan rumah sakit atau bidan, atau juga dari rumah sakit yang memerlukan back up pelayanan NICU dan PICU'

(Informan 2)

"di RS saya SC memang terbilang tinggi jumlahnya. Bahkan, bisa mencapai 70\%, lebih tinggi dari standar Depkes yaitu 40\%"

(Informan 3)

Berdasarkan data di RS terlihat grafik kisaran presentase persalinan SC pada beberapa unit studi menunjukkan trend cukup tinggi. Gambar 1 menunjukkan terdapat 1 RS swasta yang memiliki angka SC sebesar $70 \%$ dan 2 RS yang memiliki angka SC sebesar $40 \%$ dari seluruh persalinan. Beberapa RS lainnya memiliki angka rata-rata angka SC berkisar 30-35\% setiap tahunnya. Selain persentase, trend persalinan SC di setiap RS tersebut juga mengalami kenaikan setiap tahunnya.

Berdasarkan hasil penelitian diketahui bahwa determinan persalinan SC yang terjadi di RS pemerintah, cenderung diakibatkan oleh indikasi medis karena RS tersebut telah menjadi rujukan dari berbagai klinik, puskesmas dan rumah sakit di sekitar RS vertikal tersebut. Informasi tersebut 


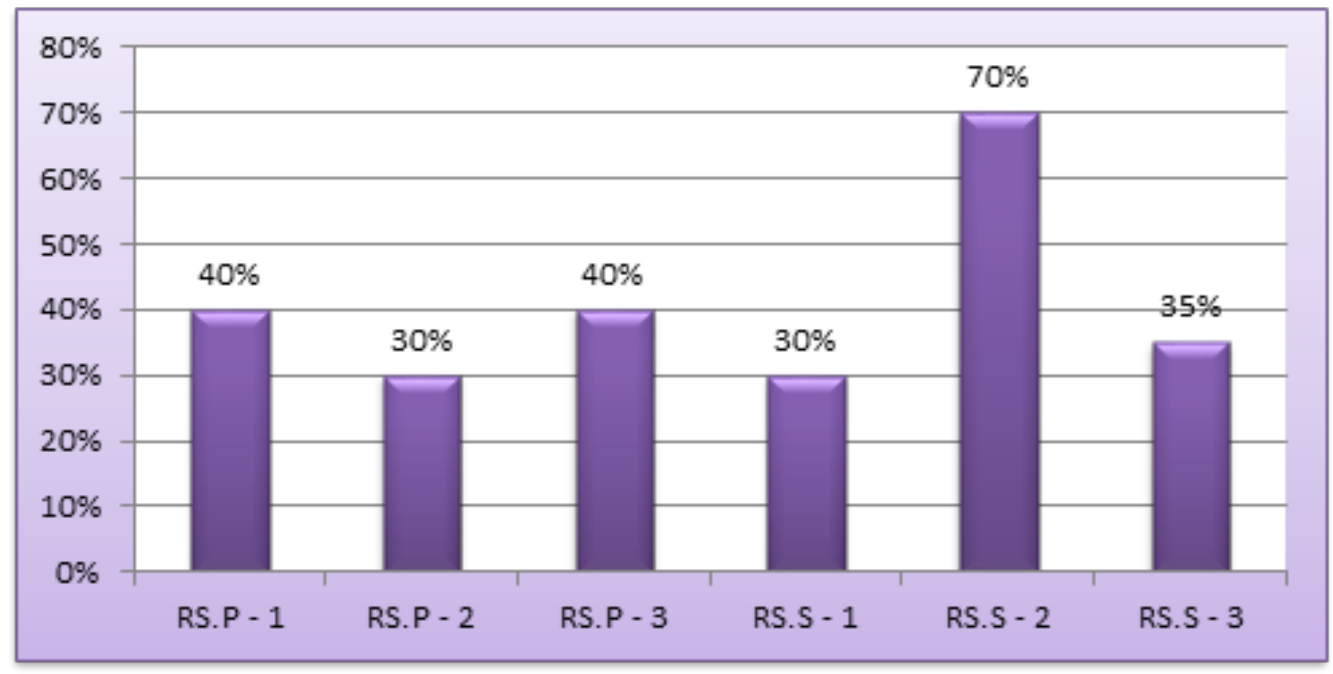

Gambar 1. Presentase Persalinan Sectio caesarea di Institusi Rumah Sakit Pemerintahan dan Swasta Tahun 2014

Tabel 1. Determinan Persalinan Sectio caesarea

\begin{tabular}{|c|c|c|c|c|}
\hline & Pasien 1 & Pasien 2 & Pasien 3 & Pasien 4 \\
\hline Masalah Kehamilan & $\begin{array}{c}\text { Ketuban Pecah Dini } \\
\text { (KPD) }\end{array}$ & "kehamilan air" & $\begin{array}{c}\text { Kegemukan, dan } 4 \\
\text { tahun yang lalu juga } \\
\text { melalui operasi SC }\end{array}$ & $\begin{array}{c}\text { Penurunan volume } \\
\text { air ketuban }\end{array}$ \\
\hline Saran dokter & $\begin{array}{c}\text { Masih disarankan } \\
\text { Partus Normal }\end{array}$ & Sectio caesarea & $\begin{array}{c}\text { Sectio caesarea/partus } \\
\text { normal }\end{array}$ & Sectio caesarea \\
\hline Keputusan akhir & Sectio caesarea & Partus normal & Sectio caesarea & Sectio caesarea \\
\hline
\end{tabular}

diringkas dari beberapa informan seperti pada Tabel 1 .

Selanjutnya pada aspek prosedur medis, dari hasil wawancara dengan narasumber, didapatkan informasi bahwa prosedur medis sebelum SC meliputi informed consent dan edukasi tentang manfaat dan risiko SC pada pasien telah dijalankan. Namun, teknis pelaksanaan informed consent dan edukasi tersebut dapat berbeda-beda, tergantung pada kondisi pasien dan jenis rumah sakit.

"(edukasi dan informed consent pada pasien) berjalan karena PPDS memiliki kewajiban untuk hal tersebut. Lagipula RSX ini adalah $R S$ tersier jadi tidak ada pelayanan bidan. Jadi pasti dokter (PPDS) yang menjelaskan walaupun tidak bisa dipungkiri pasti ada yang 'lolos' karena jumlah pasien yang sangat banyak"

(Informan 1)

"(Penjelasan tentang sectio caesarea dan informed consent) selalu dijelaskan, jika per- salinan SC dilaksanakan secara terencana tetapi untuk pelaksanaan yang dilakukan secara mendadak, baru diputuskan setelah di kamar bersalin, juga selalu ada informed consent tapi tidak banyak penjelasan"

(Informan 2).

Berdasarkan kutipan hasil wawancara diketahui bahwa teknis pelaksanaan dan hasil edukasi serta informed consent dipengaruhi oleh kondisi pasien. Jika kondisi pasien diindikasikan memiliki kelainan atau masalah persalinan serta direncanakan untuk melakukan persalinan dengan SC maka informed consent dijalankan dengan tertib, artinya dengan melalui proses diskusi antara dokter dengan pasien (calon ibu melahirkan) dan pasangan atau orang tua sehingga pihak pasien faham. Sebaliknya, dalam kondisi pasien yang tidak direncanakan bersalin dengan SC maka informed consent tidak berjalan melalui diskusi melainkan sebuah kesepakatan yang singkat diambil oleh kedua pihak, dokter dan pihak pasien. 
Persalinan melalui operasi SC pada kesempatan tertentu dilakukan tanpa indikasi medis yang kuat berdasarkan permintaan pasien. Keputusan ini dilakukan tenaga medis dengan alasan karena memilih cara persalinan adalah hak pasien, berbuat baik terhadap pasien, mempertimbangan kondisi psikis pasien, berniat adil terhadap pasien. Menghadapi hal ini tenaga medis akan memberikan edukasi kepada pasien dengan menjelaskan kelebihan dan kekurangan atau risiko tindakan SC dan komplikasinya, termasuk rencana kehamilan berikutnya. Tenaga medis tetap menghormati keputusan pasien dan keluarga, selanjutnya pasien akan membuat permohonan tertulis untuk dilakukan tindakan SC yang ditandatangani oleh pasien dan keluarga sebagai saksi, seperti kutipan informan berikut :

“...Keputusan pasien dan keluarga tersebut kita hormati karena itu merupakan hak autonomi pasien, tapi sebelum pasien dan keluarga memutuskan meminta tindakan SC kita harus menjelaskan segala risiko dan komplikasi dari tindakan SC tersebut.

(Informan 4).

“...Permintaan mesti disampaikan secara tertulis, ditandatangani juga oleh keluarga sebagai saksi, dan dokter penanggung jawab. Kita bisa menerima dan akan menjalankan keputusan pasien dan keluarga tersebut, yang sebelumnya kita sudah berikan edukasi yang jelas.

(Informan 5)

Persalinan melalui SC tanpa indikasi medis yang terjadi karena keinginan calon ibu juga ba-nyak yang disebabkan oleh masalah psikologis sebelum melahirkan, misalnya karena ibu merasakan kekhawatiran yang berlebih jika melalui persalinan secara normal sehingga secara tidak terencana menginginkan operasi sectio caesarea.

Berdasarkan hasil wawancara diketahui beberapa pertimbangan pasien dan keluarga memutuskan memilih SC antara lain karena tidak ingin merasakan sakit atau nyeri persalinan, tidak mau lama menjalani proses persalinan, tidak ingin mengalami luka atau trauma pada jalan lahir, trauma pada persalinan pervaginam (riwayat obstetri buruk sebelumnya seperti keguguran berulang, IUFD), suami atau keluarga tidak tega melihat nyeri persalinan yang dialami oleh pasien.
Apabila kondisi tersebut yang terjadi maka perlu dipertimbangkan kembali bagaimana konsekuensi yang akan terjadi nantinya. Dalam beberapa literatur disebutkan bahwa proses persalinan merupakan proses yang kompleks, tidak hanya membutuhkan kondisi fisik yang kuat melainkan pula psikologis yang siap.

\section{PEMBAHASAN}

Berdasarkan hasil penelitian diketahui bahwa trend persalinan melalui SC terbilang tinggi. Rentangnya hanya sedikit lebih rendah dari standar Kementerian Kesehatan, tetapi angka tertingginya jauh lebih tinggi dari standar tersebut. Persentase persalinan SC berkisar antara 30\%-70\% setiap tahunnya. Sementara, standar jumlah persalinan melalui SC menurut Kementerian Kesehatan dan WHO adalah masing-masing $40 \%$ dan 5-15\%.

Hasil penelitian di 3 RS di Jakarta diketahui persentase SC sekitar 55,9\% di RSUD dan 59,9\% di RS Swasta. ${ }^{13}$ Selaras dengan data di RSUPN Cipto Mangunkusumo, tahun 1999 sampai 2000, disebutkan bahwa dari sekitar 404 persalinan per bulan, 30\% diantaranya merupakan sectio caesarea. Berdasarkan persentase sectio caesarea tersebut, $13,7 \%$ disebabkan oleh gawat janin (denyut jantung janin melemah menjelang persalinan) dan $2,4 \%$ karena ukuran janin terlalu besar sehingga tidak dapat melewati panggul ibu, sementara sekitar $13,9 \%$ sectio caesarea dilakukan tanpa pertimbangan medis. ${ }^{6}$

Penelitian Suryati ${ }^{14}$ yang menyatakan bahwa angka tindakan operasi caesar di Indonesia sudah melewati batas maksimal standar WHO yaitu 5-15\%. Berdasarkan hasil Riskesdas 2010 tercatat bahwa jumlah persalinan melalui bedah caesarea secara nasional sekitar $15,3 \%$ dari jumlah total persalinan (dari 20.591 sampel ibu yang melahirkan dalam kurun waktu 5 tahun terakhir yang diwawancarai di 33 provinsi). Jumlah tindakan sectio caesarea yang cukup tinggi dan mengalami peningkatan setiap tahunnya patut menjadi perhatian. Hal ini tidak hanya terjadi pada rumah sakit swasta melainkan juga di rumah sakit pemerintah. Secara umum di Indonesia, jumlah persalinan caesarea di rumah sakit pemerintah $25 \%$ dari total persalinan, sedangkan di rumah sakit swasta jumlahnya sangat tinggi yaitu sekitar $30-80 \%$ dari total persalinan. 
Faktor risiko ibu saat melahirkan untuk dioperasi caesarea menurut Riskesdas 2010 diketahui adalah karena ketuban pecah dini $(13,4 \%)$, preeklampsiaa $(5,49 \%)$,perdarahan $(5,14 \%)$, jalan lahir tertutup $(4,40 \%)$, rahim sobek $(2,3 \%){ }^{14}$ Adanya komplikasi persalinan ini 6,63 kali lebih cenderung ibu melahirkan secara sesar dibandingkan ibu yang tidak memiliki komplikasi persalinan..$^{15}$ Penelitian lain menunjukkan bahwa faktor yang berhubungan dengan tindakan persalinan SC adalah karena alasan medis yaitu gawat janin yang berisiko hampir 12 kali lebih besar untuk persalinan SC. ${ }^{16}$ Faktor lain yang berhubungan dengan keputusan SC antara lain adalah usia ibu, paritas, dan kejadian anemia, ${ }^{17}$ serta perubahan demografi, pilihan wanita pada melahirkan, dan saran dokter. ${ }^{3}$

Dokter sebaiknya memahami aspek etika kesehatan dalam persalinan sectio caesarea. Dokter harus mematuhi etika dalam praktek klinis dan berhati-hati dalam mengevaluasi indikasi setiap CS dan mengambil keputusan yang tidak bias sebelum melakukan CS atas permintaan. Selain risiko dan manfaat, perlu pemahaman potensi risiko jangka panjang berulang CS, termasuk histerektomi dan kematian ibu dan janin. ${ }^{18}$

Berdasarkan teori deontologi (kewajiban) maka fokus analisis etika suatu tindakan dilakukan terhadap pelaksana tindakan tersebut. ${ }^{11}$ Oleh karena itu dalam persalinan, aspek etika yang dibahas fokus pada dokter atau tenaga medis yang melaksanakan. Persalinan melalui SC tanpa indikasi medis dapat dikatakan etis apabila dokter telah melakukan kewajibannya, antara lain menjelaskan kondisi janin/bayi pada orang tua, risiko-risiko yang kemungkinan terjadi saat dan setelah melalui operasi SC, serta hal-hal lain yang perlu diketahui calon ibu dan pasangannya pasca operasi SC, menjalankan prosedur informed consent dan melakukan operasi SC sesuai dengan prosedur medis yang berlaku, tanpa kesalahan sedikit pun. Sebagaimana yang telah dijelaskan mengenai kelebihan ini bahwa apabila pelaksana tindakan yang memicu dilema etis ini telah menjalankan kewajiban sesuai peran dan tanggungjawabnya maka tindakan ini tidak lagi menjadi pembahasan dalam dilema etis. Namun, kekurangannya bahwa deontologi tidak peka terhadap konsekuensi-konsekuensi tindakan, maka apabila di waktu mendatang risiko akibat persalinan SC dirasa merugikan pasien maka pa- sien tidak dapat lagi menuntut pihak tenaga medis atau dokter yang melakukan operasi SC.

Membahas suatu isu dari aspek etika diperlukan teori etika sebagai acuan dalam proses membenarkan suatu keputusan etis tertentu, atau untuk menyusun informasi yang kompleks dan nilai-nilai serta kepentingan-kepentingan yang bersaing satu sama lain, dan mencari jawaban atas pertanyaan tentang tindakan yang diperlukan dalam kondisi tertentu. Ada empat teori etika yang dapat menjadi alternatif pembahasan isu etika, antara lain: konsekuensialisme, deontologi, etika hak dan intuisionisme. ${ }^{11}$

Teori etika "konsekuensialisme" memandang bahwa tindakan yang dianggap etis adalah tindakan dengan konsekuensi yang membawa keuntungan yang lebih banyak, melebihi segala hal yang merugikan. ${ }^{11}$ Dengan menggunakan cara pandang pada teori ini, persalinan melalui SC tanpa indikasi medis bisa saja dapat disimpulkan sebagai tindakan medis yang tidak etis mengingat tindakan medis tersebut masih dianggap tidak lebih aman dan lebih berisiko meski teknologi kedokteran atau medis telah berkembang pesat dan lebih aman.

Berdasarkan 'etika hak', untuk menganalisis suatu tindakan perlu ditentukan terlebih dahulu hak dan tuntutan moral yang akan terpicu dari tindakan yang akan dilakukan. Hal yang menjadi fokus pada teori ini adalah bahwa tuntutan moral atau hak seseorang terpenuhi. Etika hak populer di Amerika Serikat, terutama dalam isu abortus. Teori hak pantas dihargai terutama karena tekanannya pada nilai moral seorang manusia dan tuntutan moralnya dalam suatu situasi konflik etis. Di sisi lain, teori ini tidak menjelaskan tentang konflik hak antara individu-individu harus dipecahkan. ${ }^{11}$ Di persalinan sectio caesarea, teori etika hak ini memecahkan dilema-dilema moral dengan terlebih dahulu menentukkan hak dan tuntunan moral mana yang terlibat di dalamnya.

Adapun pada teori intuisionisme, berdasarkan dugaan setiap individu terhadap suatu tindakan yang memicu dilema etis, ${ }^{11}$ maka teori ini tidak dapat digunakan dalam pembahasan etika kesehatan pada persalinan melalui SC tanpa indikasi medis. Hal ini dikarenakan tindakan tersebut merupakan tindakan medis yang telah memiliki standar tersendiri dan pelakunya tidak lain adalah 
profesi kesehatan, dokter, yang juga telah memiliki etika profesi. Dengan demikian, setiap tindakan medis yang dilakukan tidak dapat dinilai hanya dengan intuisi melainkan perlu dipertimbangkan secara cermat, dapat melalui aspek konsekuensi atau akibat dari tindakan tersebut, dari aspek kewajiban pelaku (dokter) yang telah terikat etika profesi, serta dapat pula mempertimbangkan hak dari penerima atau penentu tindakan tersebut yang dalam hal ini adalah pasien atau calon ibu yang akan melahirkan.

Beauchamp dan Childress menyebutkan bahwa terdapat 4 poin prinsipal dalam moral dan etik kesehatan yaitu Autonomy, Beneficience, Non-maleficence, dan Justice. ${ }^{12}$ Keempat poin tersebut harus seimbang, dan pada suatu kondisi mungkin saja terjadi jika salah satu poin etik akan kontra dengan poin yang lainnya.

Di Indonesia, dalam Pertemuan Ilmiah Tahunan (PIT) POGI yang terakhir di Jakarta, Juli 2011 telah disepakati untuk dilakukan perubahan pada standar kode etik POGI yang menyatakan bahwa tindakan sectio caesarea atas permintaan pasien bukanlah merupakan suatu bentuk pelanggaran etik selama dilakukan suatu informed consent khusus, yaitu adanya surat persetujuan tindakan medik bedah caesar dengan format khusus dan dijelaskan langsung oleh dokter yang akan melakukan tindakan, didampingi saksi dari pihak dokter, dan saksi dari pihak pasien, yang berisi: 1) Permintaan secara eksplisit tertulis bahwa dengan ini pasien meminta untuk dilakukan tindakan seksio sesarea, 2) Bahwa pasien telah dijelaskan oleh dokter yang membedah tentang; persalinan secara caesar akan dilakukan walaupun telah dilakukan pemeriksaan oleh dokter bahwa pasien dapat melahirkan per vaginam, persalinan melalui caesar tidak lebih baik jika dibandingkan dengan persalinan per vaginam, adanya risiko yang dapat timbul pada ibu dan janin berkaitan dengan tindakan bedah caesar. ${ }^{19}$

Berdasarkan Kode Etika Kedokteran Indonesia (KODEKI) yang berpedoman dari Surat Keputusan PB IDI No 221/PB/A-4/04/2002, Pasal $7 \mathrm{c}$ berbunyi "Seorang dokter harus menghormati hak-hak pasien, hak-hak sejawat, dan hak tenaga kesehatan lainnya, dan harus menjaga kepercayaan pasien." Oleh karena itu, jika pasien menginginkan dan memutuskan untuk dilakukannya opera- si caesar, maka dokter harus mempertimbangkan untuk menyetujui kehendak pasien (dengan tetap mempertimbangkan keamanan bagi pasien) karena pasien mempunyai haknya sendiri untuk menentukan tindakan medis yang akan dilakukan.

Selain itu alasan yang mendasari terbitnya revisi kode etik POGI adalah Undang-Undang Praktik Kedokteran yang memuat mengenai hak pasien atas pilihan pengobatan pada dirinya, hak mendapatkan penjelasan atas tindakan medik (dijelaskan untung rugi, risiko yang dihadapi selama pembedahan dan masa mendatang), serta hak untuk menolak tindakan medis pada dirinya. Dalam hal ini pasien memilih untuk dilakukan persalinan secara SC.

Perlu menjadi perhatian bersama jika terjadi malpraktik akibat SC ini antara lain bahwa rumah sakit bertanggung jawab atas kelalaian tenaga medis di rumah sakit akibat dari perbuatan tenaga medis yang merugikan pasien atas dasar yuridis mormatif sesuai ketentuan Pasal 1367 KUH Perdata, dan Pasal 46 UU rumah sakit, dan standar profesi dan akreditasi pelayanan kesehatan secara internasional. Akan tetapi tindakan tenaga medis dalam bentuk criminal malpractice, maka akan tetap dipertanggungjawabkan pada tenaga medis tersebut. ${ }^{20}$ Oleh karena itu, semua pihak diharapkan dapat mengutamakan tanggung jawab profesionalisme di bidang kesehatan, khususnya bagi tenaga medis yang berhubungan langsung dengan pasien

\section{KESIMPULAN DAN SARAN}

Dapat disimpulkan bahwa trend persalinan melalui sectio caesarea sangat tinggi yakni berkisar antara 30\% sampai $70 \%$, baik di rumah sakit pemerintah maupun swasta. Persalinan sectio caesarea hampir seluruhnya disebabkan indikasi medis. Trend yang tinggi pada persalinan melalui tindakan sectio caesarea tidak serta merta menunjukkan bahwa terdapat hal yang bertentangan dengan etika pelayanan kesehatan. Banyak faktor di luar indikasi medis, baik dari sisi ibu maupun bayi yang menyebabkan dipilihnya tindakan sectio caesarea. Berdasarkan teori etika konsekuensialisme, persalinan melalui SC tanpa indikasi medis bisa dinilai sebagai tindakan medis yang tidak etis mengingat tindakan medis tersebut masih dianggap tidak lebih aman dan lebih berisiko mes- 
ki teknologi kedokteran telah berkembang pesat. Menurut teori deontologi (kewajiban), persalinan melalui SC tanpa indikasi medis dapat dikatakan etis apabila dokter telah melakukan kewajibannya, jika telah menjalankan prosedur informed consent dan melakukan operasi SC sesuai dengan prosedur medis yang berlaku, tanpa kesalahan sedikit pun.

\section{UCAPAN TERIMA KASIH}

Ucapan terima kasih disampaikan kepada Novi Dwi Istanti dan Putri Kurniasari dari FKM Universitas Indonesia serta kepada semua pihak yang terlibat dan membantu dalam penelitian ini.

\section{DAFTAR RUJUKAN}

1. Chu K, Cortier H, Maldonado F, Mashant T, Ford N, Trelles M. Cesarean Section Rates and Indications in Sub-Saharan Africa: a Multi-country Study from Medecins Sans Frontieres. PLOS one. 2012;7(9 e44484):1-6.

2. Sur S, Mackenzie I. Does Discussion of Possible Scar Rupture Influence Preferred Mode of Delivery After a Caesarean Section? Journal of Obstetrics and Gynaecology. 2005;25(4):33841.

3. Dobson R. Caesarean Section Rate in England and Wales Hits 21. BMJ: British Medical Journal. 2001;323(7319):951.

4. Wagner VV, Young D. Choosing a Caesarean Birth - A Forum to Discuss the Issues. Atlantic Centre of Excellence for Women's Health; June 16th 2002; Canada 2002.

5. Juditha I, Cynthia I. Tips Praktis bagi Wanita Hamil. Jakarta: Forum Kita; 2009.

6. Kasdu D. Operasi Caesar: Masalah dan solusinya. Jakarta: Puspa Swara; 2003.

7. Elizabeth. Menyambut Kehadiran Buah Hati. Jakarta: Openup Publishing; 2005.

8. Salfariani I, Nasution SS. Faktor Pemilihan Persalinan Sectio Caesarea Tanpa Indikasi Medis Di RSU Bunda Thamrin Medan. Jurnal Keperawatan. 2012;1(1):7-12.

9. Mochtar R. Sinopsis Obstetri Jilid II. Jakarta: EGC; 2002.
10. Lumbiganon P, Laopaiboon M, Gülmezoglu AM, Souza JP, Taneepanichskul S, Ruyan P, et al. Method of Delivery and Pregnancy Outcomes in Asia: the WHO Global Survey on Maternal and Perinatal Health 2007-08. The Lancet. 2010;375(9713):490-9.

11. Shannon TA. Pengantar Bioetika (diterjemahkan oleh K. Bertens). Jakarta: Gramedia Pustaka Utama; 1995.

12. Beauchamp TL, Childress JF. Principles of Biomedical Ethics. New York: Oxford University Press; 1994.

13. Sihombing M, Andayasari L. Determinan Persalinan Seksio Sesarea Pasien Kelas Tiga Di Dua Rumah Sakit Di Jakarta Tahun 2011. Jurnal Kesehatan Reproduksi. 2015;6(3):173-81.

14. Suryati T. (Analisis lanjut data Riskesdas 2010) Persentase Operasi Caesaria di Indonesia Melebihi Standard Maksimal, Apakah Sesuai Indikasi Medis. Buletin Penelitian Sistem Kesehatan. 2013;15(4):331-8.

15. Sihombing N, Saptarini I, Putri DSK. Determinan Persalinan Sectio Caesarea di Indonesia (Analisis Lanjut Data Riskesdas 2013). Jurnal Kesehatan Reproduksi. 2017;8(1):63-75.

16. Andayasari L, Muljati S, Sihombing M, Arlinda D, Opitasari C, Mogsa DF, et al. Proporsi Seksio Sesarea dan Faktor yang berhubungan dengan Seksio Sesaria di Jakarta. Buletin Penelitian Kesehatan. 2015;43(2):105-16.

17. Mulyawati I, Azam M, Ningrum DNA. Faktor Tindakan Persalinan Operasi Sectio Caesarea. Jurnal Kesehatan Masyarakat. 2011;7(1):1421.

18. Mukherjee S. Rising cesarean section rate. J Obstet Gynecol India. 2006;56(4):298-300.

19. POGI. Tindakan Caesar atas Permintaan Sendiri. Jakarta: Himpunan Kedokteran Feto Maternal POGI; 2011.

20. Wahyudi S. Tanggung Jawab Rumah Sakit Terhadap Kerugian Akibat Kelalaian Tenaga Kesehatan dan Implikasinya. Jurnal Dinamika Hukum. 2011;11(3):505-21. 